COMMENTARY

\section{Sogorea Te' Land Trust empowers indigenous food sovereignty in the San Francisco Bay Area}

Special JAFSCD Issue

Indigenous Food Sovereignty in North America
sponsored by Swette Center for
Sustainable Food Systems Arizona State University

\author{
K. Nicole Wires a ${ }^{*}$ \\ Planting Justice \\ Johnella LaRose ${ }^{b}$ \\ Sogorea Te' Land Trust
}

Submitted January 16, 2019/ Accepted January 16, 2019 / Published online November 22, 2019

Citation: Wires, K. N., \& LaRose, J. (2019). Sogorea Te' Land Trust empowers indigenous food sovereignty in the San Francisco Bay Area. Journal of Agriculture, Food Systems, and Community

Development, 9(Supppl. 2), 31-34. https://doi.org/10.5304/jafscd.2019.09B.003

Copyright (C 2019 by the Authors. Published by the Lyson Center for Civic Agriculture and Food Systems. Open access under CC-BY license.

\begin{abstract}
Indigenous food sovereignty is about much more than consumption choices, food access, and traditional knowledge; it is fundamentally about access to land for sacred ceremony and traditional practice. This article will highlight an innovative case study in indigenous land "rematriation" (returning the land to its original stewards and inhabitants) on the occupied lands of the Chochenyo and Karkin Ohlone peoples, also known as Oakland or the East San Francisco Bay Area of California, through a partnership with Sogorea Te' Land Trust, an urban indigenous women-led land trust, and
\end{abstract}

a * Corresponding author: K. Nicole Wires, Permaculture Designer, Planting Justice; $319105^{\text {th }}$ Avenue; Oakland, CA 94603 USA; nicole@plantingjustice.org

b Johnella LaRose, Sogorea Te' Land Trust; 2501 Harrison St.; Oakland, CA 94612 USA; sogoreatelandtrust@gmail.com; details at https://sogoreate-landtrust.com/shuumi-land-tax/
Planting Justice, a food-justice nonprofit based in Oakland.

\section{Keywords}

Indigenous Food Sovereignty, Land Trust, Native Food Pathways, Traditional Ecological Knowledge (TEK), Food Justice, Land Access, Sacred Site Protection

\section{History of the Ohlone People}

The Ohlone people are the native people of the San Francisco Bay Area. Like all native peoples, their diversity is vast. The Ohlone lived in approximately 50 documented villages and extended family groups before the European

\section{Disclosure}

Nicole Wires works for and is paid by Planting Justice, and Johnella LaRose is co-founder and employed by Sogorea Te' Land Trust, the organizations discussed in this paper. 
invasion and spoke at least eight dialects of related languages. The Ohlone people share similar histories and a relationship to the diverse San Francisco Bay bioregion, but they have never constituted a single political or cultural entity. This diversity is reflected today in the broad spectrum of culturally and politically active Ohlone families and tribes (Sogorea Te' Land Trust, n.d.-a).

As with many of the California Native peoples, the Ohlone were forced into missions and residential schools and tortured under the reign of terror imposed by colonial empires, first from Spain, then from Mexico, and finally from the United States. Mission San Carlos in San Jose was established by Franciscan missionaries in 1769. These missionaries desired to convert all Indians into Catholic subjects of Spain. Survivors of the violence of missionization, which forced native people to abandon their languages and cultural practices, then faced extermination through the genocidal policies of the United States government, which paid settlers for scalps of Indian men, women, and children with the goal of eliminating California Indians entirely. Facing state-sponsored vigilante killings and virulent racial discrimination, many Ohlone families concealed their native identities, passing as "Mexican" or isolating themselves in order to survive. As a result, cultural and spiritual traditions were forced into dormancy or secrecy, and much knowledge perished with the passing of generations ( Sogorea Te' Land Trust, n.d.-a). Corrina Gould, the spokesperson for the Confederated Villages of Lisjan and a co-founder of Sogorea Te' Land Trust, states that despite its progressive reputation, California has systematically strived to "totally invisibilize the Native Americans who lived here for thousands of years" (Aguilar \& Wenus, 2018).

Since the beginning of colonial contact and continuing to the present day, the Ohlone have been denied the right to exist as Indigenous people. The U.S. federal government has refused to officially recognize the Ohlone as tribes, which denies access to reservations or protected land bases for the Ohlone tribes and the thousands of Ohlone people alive today, as well as to the rights, benefits, compensations, and protections afforded to Indians under treaties and centuries of federal
Indian laws ( Sogorea Te' Land Trust, n.d.-a). The benefits that the Ohlone are excluded from, in addition to reservations and land bases, include Indian Health Care services, federal scholarships, housing grants, and protections for cultural, burial, and sacred sites ( Sogorea Te' Land Trust, n.d.-a).

The process by which unrecognized tribes can apply for recognition is called the Federal Acknowledgment Process, which is managed by the Bureau of Indian Affairs (BIA). Tribes must submit thousands of pages of evidence to prove who they are; criteria for recognition include demonstrating an unbroken continuity of leadership, tribal culture, and organization. The costs for presenting this proof are born entirely by the tribe. This standard is nearly impossible to achieve, given that California's Indian policy and the enslavement of California Indians in missions deliberately sought to dismantle the very continuity tribes are being asked to demonstrate. Ohlone tribes have submitted eight petitions for federal recognition since 1988, and not a single one has led to approval ( Sogorea Te' Land Trust, n.d.-a).

In addition to Chochenyo and Karkin Ohlone people, the Bay Area is home to a diverse global Indigenous community as a result of the Indigenous diaspora that resulted from the U.S. government's Indian termination policies, as well as more contemporary diasporas resulting from global capitalism and empire through Latin America, the Pacific Islands, and across the globe ( Sogorea Te' Land Trust, n.d.-b). Specifically, the Indian Relocation Act of 1956 was a federal law intended to encourage Native Americans in the U.S. to leave Indian reservations, acquire vocational skills, and assimilate into the general population. Part of the Indian termination policy of that era, which terminated the tribal status of numerous groups, the act played a significant role in increasing the population of urban Indians in succeeding decades.

Stemming from this diverse population of indigenous people in the East Bay Area who have been systematically dispossessed from their land, an innovative solution to urban indigenous land access was envisioned: Sogorea Te' Land Trust.

\section{The Vision of Sogorea Te' Land Trust}

Sogorea Te' Land Trust is an urban, intertribal, 
Indigenous- and women-led land trust created to support Chochenyo and Karkin Ohlone, as well as other intertribal Indigenous people, in the Bay Area in order to gain title and legal access to land for sacred site protection, ceremony, and reclaiming indigenous food pathways and land stewardship. With the existence of the land trust, Sogorea Te' can acquire land through direct donation and title transfer from existing owners, or fundraising that allows for the purchase of land. Other legal mechanisms that protect access to land, including cultural easements, can also be granted. Sogorea Te' Land Trust names this process of returning land to the indigenous stewards "rematriation," recognizing the ways that native land stewardship also can undermine the patriarchal paradigm of capitalistic landownership and possession.

The vision of Sogorea Te' Land Trust is multiple, including to restore native land stewardship to the original inhabitants of the land, to restore native foodways and traditional ecological knowledge, and to create sacred space for ceremony to allow the Chochenyo and Karkin Ohlone people to carry out their sacred obligations from their creator on the land. Says Corrina Gould, a co-founder of Sogorea Te' Land Trust, “The land trust will also make it possible for us to relearn our traditional methods of taking care of the land. We can begin bringing back some of our traditional foods, like acorns. With that comes ways of taking care of the land such as [prescribed] burning. Burning also helps to bring back some of those native plants that were here before, so that we can bring back the basket weaving, that we can bring back the medicines that were always here, that we can begin to teach ourselves how it is that we are supposed to live on this land again" ( Sogorea Te' Land Trust, Our Vision, n. d., para. 13).

Additionally, with legally protected access provided by a cultural easement, Sogorea Te' Land Trust will enable Indigenous people in the Bay Area to have influence over decisions made by land-use managers on public lands. "There's a lot of open space parks in the Bay Area, set up for recreation. With the land trust, we would like to establish cultural easements on those lands so that we can practice our cultural belief systems, protect our sacred places, and actually have a voice over what happens there. We are not a special interest group, like many park districts or parks often assume-we are the original caretakers of this land. With easements, we could actually have a say-an equal say-in what happens on those lands," states Gould ( Sogorea Te' Land Trust, n.d.-b, para. 14).

The land trust envisions building spaces for community engagement, including community gardens for local native food sovereignty, on some urban parcels of land that can be acquired through the trust. As Johnella LaRose, another co-founder of Sogorea Te' Land Trust, says, "In the Indian community, we're in a crisis around food, and we have no place to grow this food. There are many community gardens in the Bay Area, but the native community does not have one. We do not have one. We need that kind of space to grow food, spaces where everybody could come and gather-safe space for young people, children, and families to be” ( Sogorea Te' Land Trust, n.d.-b, para. 15). Adds Gould, "Getting back to traditional and sustainable foods is also important for us because as native people, we have some of the highest rates of diabetes and heart disease and all of these other horrible things that came with western culture. By going back to our original food sources, we can start reversing that. We can heal ourselves with the food that was always here for us" ( Sogorea Te' Land Trust, n.d.-b, para. 17).

The lack of access to traditional ceremonial grounds and to land appropriate for multiday ceremonies is a troubling challenge faced by Ohlone people today, since the tribes remain without land in the Bay Area. A cornerstone of Sogorea Te' Land Trust's vision is the construction of a traditional Ohlone roundhouse in the East Bay area that would welcome all Ohlone families and bands, acting as a space for healing and spiritual renewal. A roundhouse would be a spiritual center for the Ohlone people in the East Bay, allowing them to enact the obligations they have from their creator; as Corrina Gould says, "to sing and dance our songs here to heal the land" (Dalmas, 2018).

\section{Partnership with Planting Justice}

With this righteous vision in place, Sogorea 'Te' Land Trust formed a partnership in 2017 with Planting Justice, a food-justice nonprofit based in 
Oakland with a mission "to empower people affected by mass incarceration and other social inequities with the skills and resources to cultivate food sovereignty, economic justice, and community healing" (Planting Justice, n.d., para. 1). Founded in 2008, Planting Justice creates meaningful, living-wage jobs in the sustainable food system for youths and adults impacted by incarceration. It operates a permaculture landscaping company, an organic-certified commercial nursery, an urban farm and orchard that serve as the mother farm for the nursery, and a grassroots canvassing team. In 2016, Planting Justice acquired 2.5 acres (1.0 hectare) of land in East Oakland for the operation of its commercial nursery, Rolling River Nursery.

Through relationship-building, Planting Justice and Sogorea Te' Land Trust entered into an agreement to grant a cultural easement, and eventually to transfer full title, of the land operated as the Rolling River Nursery in East Oakland. Currently, Planting Justice owes debt on the land through a mortgage; however, once it is paid off, Planting Justice has committed to transferring title of the land to Sogorea Te' Land Trust, with an agreement to lease back the land to operate Rolling River Nursery. Additionally, a cultural easement will permanently protect the back quarter-acre $(0.10 \mathrm{ha})$ of the property as an Ohlone cultural site, no matter who owns the land in the future. On this quarter-acre, a traditional arbor and fire pit are being built to create space for traditional dances, and native and traditional medicinal and basketweaving plants are being planted for cultivation and reclamation of ancestral foodways and land stewardship practices. Under this structure, both organizations will work on the land, with Sogorea Te' Land Trust having final control over land use and operations (G. Raders, personal communication, January 2018).

With unimpeded and protected land access, the Chochenyo and Karkin Ohlone people can begin the true path to community healing, wellness, land stewardship, and food sovereignty.

This land trust is a way for us as human beings to come back to being human beings. A way for us to learn how to treat each other with respect. A way for us to re-envision the Bay Area. We can create a healing for the people that are here. Not just the Ohlone people, but all people that exist on this land.

- Corrina Gould (Sogorea Te' Land Trust, Our Vision, n. d., para. 22)

\section{References}

Aguilar, R., \& Wenus, L. (2018, May 16). How should California reconcile its genocidal past? [Radio program episode]. In R. Aguilar (Producer), Your Call. San Francisco: KAWL. Retrieved from https://www.kalw.org/post/how-should-california-reconcile-its-genocidal-past\#stream/0

Dalmas, J. (2018, April 16). Native Americans ask East Bay residents to pay 'tax' on land [Radio program episode]. In H. Baba (Producer), Crosscurrents. San Francisco: KALW. Retrieved from https://www.kalw.org/post/native-americans-ask-east-bay-residents-pay-tax-land\#stream/0

Planting Justice. (n.d.). Home. Retrieved September 4, 2019, from http://plantingjustice.org/

Sogorea Te' Land Trust. (n.d.-a). Contemporary Oblone history. Oakland, CA: Sogorea Te' Land Trust. Retrieved September 4, 2019, from https://sogoreate-landtrust.com/contemporary-ohlone-history/

Sogorea Te' Land Trust. (n.d.-b). Our vision. Oakland, CA: Sogorea Te’ Land Trust. Retrieved September 4, 2019, from https://sogoreate-landtrust.com/our-vision/ 